\title{
PENGARUH PEMBANGUNAN TEKNOLOGI INFORMASI DAN KOMUNIKASI TERHADAP PEMBANGUNAN KAWASAN TIMUR INDONESIA
}

\author{
Arief Rahmanda Al-Mursyid \\ Email: arief.almursyid@bps.go.id \\ BPS Kabupaten Pohuwato \\ Jalan P. Diponegoro Kompleks Blok Plan Perkantoran Marisa
}

\begin{abstract}
ABSTRAK
Penelitian ini bertujuan untuk mengetahui pengaruh pembangunan teknologi informasi dan komunikasi terhadap pembangunan manusia di Kawasan Timur Indonesia. Data yang digunakan dalam penelitian ini adalah Indeks Pembangunan Teknologi, Informasi, dan Komunikasi (IP TIK) dan Indeks Pembangunan Manusia (IPM) 17 Provinsi di Kawasan Timur Indonesia tahun 2015-2017. Metode Analisis Regresi Data Panel digunakan dalam penelitian ini untuk mengetahui pengaruh pembangunan teknologi, informasi, dan komunikasi (TIK) terhadap pembangunan manusia di Kawasan Timur Indonesia. Hasil dari penelitian ini menunjukan bahwa pembangunan TIK memiliki pengaruh yang positif dan signifikan terhadap pembangunan manusia di Kawasan Timur Indonesia. Provinsi Sulawesi Barat, NTT, Papua Barat, dan Papua merupakan provinsi yang masih tertinggal dan memerlukan perhatian lebih dalam pembangunan TIK di provinsi tersebut.
\end{abstract}

Kata Kunci: IP TIK; IPM; regresi data panel.

\begin{abstract}
This study aims to determine the effect of information and communication technology development on human development in Eastern Indonesia. The data used in this research are the Technology, Information, and Communication Development Index (ICT) and the Human Development Index (HDI) of 17 Provinces in Eastern Indonesia in 2015-2017. Panel Data Regression Analysis Method is used in this study to determine the effect of technology, information, and communication development (ICT) on human development in Eastern Indonesia. The results of this study indicated that ICT development has a positive and significant influence on human development in Eastern Indonesia. The provinces of West Sulawesi, NTT, West Papua and Papua are provinces that are still lagging and need more attention in developing ICT in the region.
\end{abstract}

Keywords: IP ICT; HDI; panel data regression.

\section{PENDAHULUAN}

Negara Indonesia dikenal sebagai negara kepulauan. Hal ini menjadi tantangan tersendiri bagi percepatan pembangunan di Indonesia. Salah satunya adalah besarnya ketimpangan pembangunan antar wilayah di Indonesia. Menurut Firdaus, M. (2013), ketimpangan pembangunan antar wilayah di Indonesia menempati peringkat terburuk bila diambil perbandingan dengan beberapa negara baik maju maupun berkembang. Pembangunan di Kawasan Timur Indonesia masih jauh tertinggal jika dibandingkan dengan Kawasan Barat Indonesia (Maryati, S. 2015). Salah satu data yang dapat 
menunjukkan adanya ketimpangan pembangunan antara wilayah Timur dan Barat Indonesia adalah dengan membandingkan Indeks Pembangunan Manusia (IPM).

IPM sendiri didefinisikan sebagai gambaran komprehensif mengenai tingkat pembangunan manusia di suatu daerah, sebagai dampak dari kegiatan pembangunan yang dilakukan di daerah tersebut (BPS, 2014). IPM diukur dengan menggunakan pendekatan tiga dimensi dasar manusia, yaitu umur panjang dan sehat, pengetahuan, dan standar hidup yang layak. Dimensi umur panjang dan sehat diwakili oleh indikator harapan hidup saat lahir. Dimensi pengetahuan diwakili oleh indikator harapan lama sekolah dan rata-rata lama sekolah, sedangkan dimensi standar hidup layak diwakili oleh pengeluaran per kapita. Ketiga dimensi ini terangkum dalam suatu indeks komposit yang membentuk IPM. Menurut Palenewen, dkk. (2018), IPM adalah sebagai salah satu tolak ukur kinerja pembangunan secara keseluruhan.

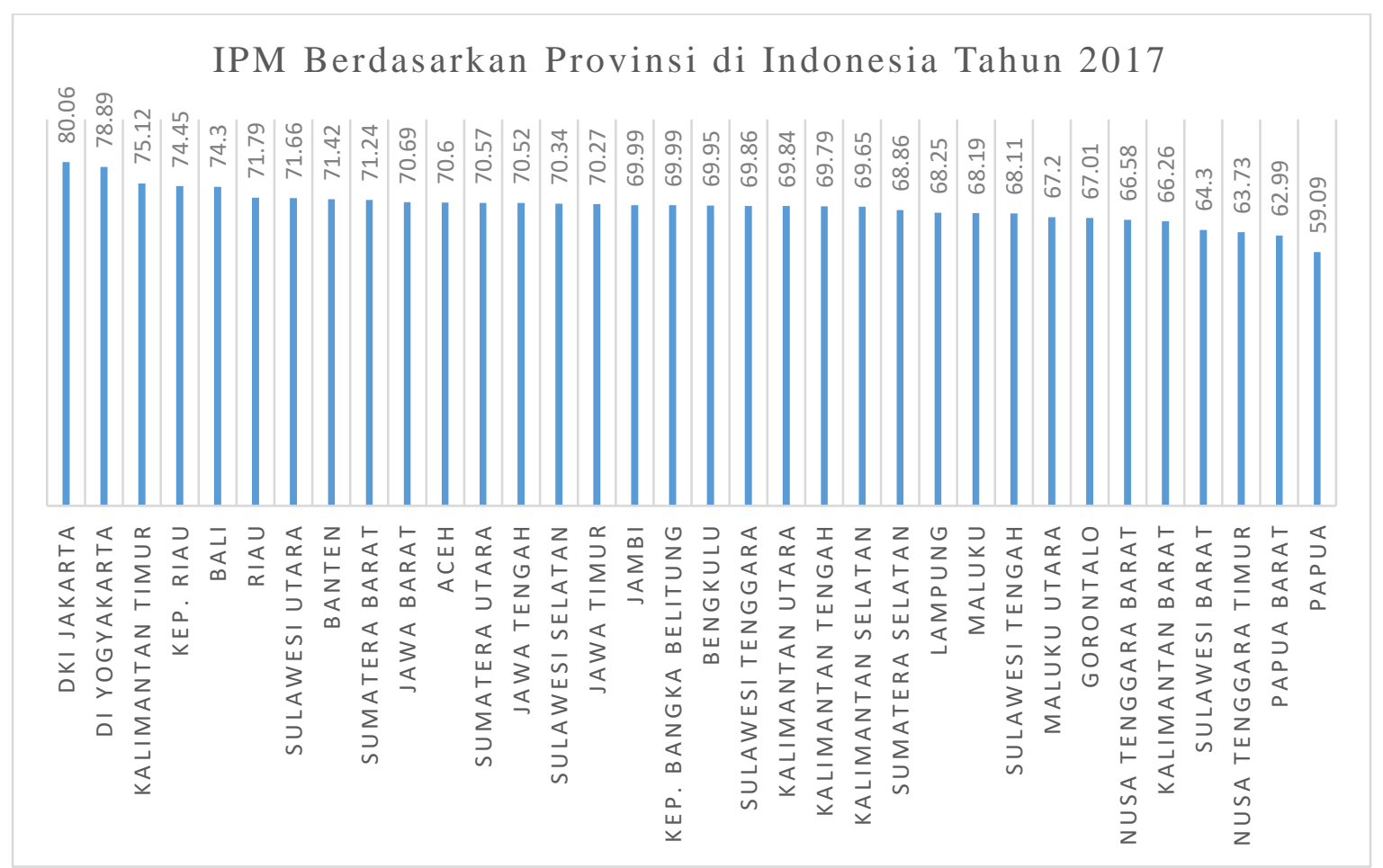

Gambar 1. IPM Berdasarkan Provinsi di Indonesia Tahun 2017

Dari Gambar 1, Provinsi DKI Jakarta merupakan satu-satunya provinsi yang masuk dalam kategori IPM sangat tinggi $(\geq 80), 14$ provinsi masuk kedalam kategori IPM tinggi $(70 \leq$ IPM $<80)$, 18 provinsi masuk kedalam kategori IPM sedang $(60 \leq$ IPM $<70)$, dan Provinsi Papua mejadi satu-satunya provinsi yang masih masuk kedalam IPM kategori rendah $(50 \leq \mathrm{IPM}<60)$. Besarnya gap IPM antara Provinsi DKI Jakarta dan Papua menunjukkan belum meratanya pembangunan di Indonesia. 
Dari Gambar 1 juga dapat dilihat bahwa provinsi-provinsi yang berada di kawasan barat Indonesia mendominasi peringkat atas IPM berdasarkan provinsi di Indonesia, sedangkan provinsi yang berada di kawasan timur berada pada peringkat menengah kebawah. Ratarata IPM provinsi di Kawasan Barat Indonesia sudah mencapai 71,87 atau masuk kedalam kategori tinggi, sedangkan provinsi di Kawasan Timur Indonesia hanya memiliki rata-rata IPM sebesar 67,63 atau berada dalam kategori sedang.

Saat ini, dunia telah memasuki era digital. Teknologi, Informasi, dan Komunikasi (TIK) sudah menjadi faktor penting kemajuan suatu wilayah. Negara seperti Jepang (Zuhdi, dkk., 2012) dan Korea Selatan (Minah, 2014) telah membuktikan, dengan memanfaatkan teknologi suatu negara dapat mempercepat pertumbuhan dan pembangunan negara. Menurut Agustina dan Pramana (2019), TIK telah menjadi katalis dalam pertumbuhan ekonomi, yang dapat dilihat dari meluasnya penggunaan aplikasi yang berdampak pada proses yang lebih efisien dalam kegiatan produksi, distribusi, dan konsumsi barang dan jasa. Oleh karena itu, kemajuan Teknologi Informasi dan Komunikasi dapat membawa dampak positif dalam berbagai bidang (Septano, 2016).

Teknologi Informasi dan Komunikasi (TIK) diartikan sebagai seluruh peralatan teknis yang digunakan untuk memproses dan menyampaikan informasi (Wahyuningsih, 2013). TIK terdiri dari dua aspek yakni, teknologi informasi dan teknologi komunikasi. Teknologi informasi sendiri merupakan segala hal yang berkaitan dengan proses, penggunaan sebagai alat bantu, manipulasi, dan pengelolaan informasi. Teknologi komunikasi diartikan sebagai segala sesuatu yang berkaitan dengan penggunaan alat bantu untuk memproses dan mentransfer data dari perangkat yang satu ke lainnya.

Tingkat kemajuan teknologi informasi dan komunikasi (TIK) suatu daerah dapat ditunjukkan melalui Indeks Pembangunan Teknologi, Informasi, dan Komunikasi (IP TIK) (BPS, 2016). IP TIK dikembangkan oleh Internasional Telecommunication Union (ITU) tahun 2008. Indeks ini merupakan suatu indeks komposit yang disusun oleh 11 indikator yang terbagi kedalam 3 subindeks yakni subindeks akses dan infrastruktur, subindeks penggunaan, dan subindeks keahlian.

Subindeks akses dan infrastruktur yang disusun dari 5 indikator yakni pelanggan telepon tetap per 100 penduduk, pelanggan telepon seluler per 100 penduduk, bandwidth internet internasional per pengguna, persentase rumah tangga yang menguasai computer, dan persentase rumah tangga yang memiliki akses internet. Lalu, subindeks penggunaan disusun dengan 3 indikator yakni persentase penduduk yang mengakses internet, 
pelanggan internet broadband tetap kabel per 100 penduduk, dan pelanggan internet broadband tanpa kabel per 100 penduduk. Selanjutnya, subindeks keahlian disusun dengan 3 indikator yakni rata-rata lama sekolah, angka partisipasi kasar sekunder (SMP sederajat dan SMA sederajat), dan angka partisipasi kasar tersier (pendidikan tinggi D1-S1).

Dari 11 indikator yang terangkum dalam tiga subindeks tersebut maka dapat dilakukan estimasi dengan rumus rata-rata tertimbang, dengan porsi 40 persen untuk subindeks akses dan infrastruktur, 40 persen untuk subindeks penggunaan, dan 20 persen untuk subindeks keahlian. Semakin tinggi nilai indeks menunjukkan pembangunan TIK suatu wilayah semakin baik sebaliknya, semakin rendah nilai indeks menunjukkan pembangunan TIK di suatu wilayah relatif masih lambat.

Bongo (2005) dalam menelitiannya, menatakan bahwa TIK memiliki kontribusi yang besar terhadapa pertumbuhan ekonomi, dimanadalam bisnis proses, penggunaan teknologi dapat membuat setiap proses lebih cepat dan murah dan juga meningkatkan produksi. Hal senada diutarakan oleh Niebel (2014) dalam penelitiannya. Dalam penelitiannya yang meneliti pengaruh TIK terhadap pertumbuhan ekonomi dengan menggunakan 59 sampel negara berkembang mengatakan adanya hubungan yang positif antara TIK dan pertumbuhan ekonomi.

Agustina dan Pramana (2019) mengatakan bahwa, pembangunan TIK dan pengeluaran pemerintah di bidang TIK memiliki pengaruh posisif dan signifikan terhadap pertumbuhan ekonomi di Indonesia. Pada penelitian tersebut ditemukan adanya ketimpangan/gap yang sangat besar pada pembangunan TIK antara provinsi-provinsi di Indonesia. Dikatakan bahwa provinsi-provinsi di Kawasan Timur Indonesia seperti NTT dan Papua lambat dan sangat tertinggal dalam pembangunan TIK.

Tidak hanya memengaruhi ekonomi saja, lebih lanjut Rosales, et al., (2019) dalam penelitiannya mengatakan bahwa perkembanagn TIK juga memengaruhi pembangunan manusia. Hal tersebut berarti pembangunan TIK tidak hanya memiliki pengaruh positif terhadap ekonomi, tetapi di bidang kesehatan dan pendidikan pula.

Hal tersebut diamini oleh Bankole, et al., (2011a) dalam penelitiannya yang menyatakan adanya pengaruh yang signifikan dari pembangunan TIK terhadap pembangunan manusia. Penelitian tersebut mengambil lokus di Negara Afrika Selatan. Dalam penelitian lain Bankole, et al., (2011b) menyatakan investasi di bidang TIK baik di negara berpendapatan tinggi, negara berpendapatan menengah, dan negara berpendapatan rendah tetap menjadi factor kunci meningkatnya pembangunan manusia di negara tersebut. 
Sedikit berbeda, Sabbagh, et al., (2012) mengatakan digitalisasi mendukung penyampaian layanan dasar pemerintah yang lebih baik, seperti pendidikan publik. Penelitian ini mengatakan bahwa dampak digitalisasi pada indeks dan subindeks pembangunan manusia lebih menonjol dalam kasus negara-negara berkembang.

Berbeda dengan penelitian diatas Morawczynski (2007) mengatakan bahwa ICT saja tidak cukup signifikan berpengaruh pada pembangunan manusia. Studi yang mengambil lokus di 5 negara Afrika Bagian Barat yakni, Benin, Kamerun, Senegal, Pantai Gading, dan Niger mengatakan investasi dalam pendidikan dan pelayan kesehatan harus diberikan pertimbangan yang sama. Dengan begitu, investasi di bidang TIK diharapkan dapat mendorong pembangunan manusia di 5 negara di Afrika Barat tersebut.

Penelitian yang membahas tentang pengaruh pembangunan TIK terhadap pembangunan manusia di Kawasan Timur Indonesia masih sangat sedikit. Dengan demikian, penelitian ini diharapkan dapat mengetahui pengaruh pembangunan TIK terhadap pembangunan manusia di Kawasan Indonnesia Timur periode 2015-2017. Penelitian ini diharaokan dapat dijadikan referensi untuk penelitian selanjutanya yang berkaitan dengan penelitian ini. Penelitian ini juga diharapkan dapat menjadi saran bagi pemerintah untuk menjadi dasar kebijakan pembangunam manusia di Kawasan Timur Indonesia.

\section{METODE PENELITIAN}

Cakupan wilayah dalam penelitian ini terdiri dari 17 provinsi di Kawasan Timur Indonesia (KTI) pada tahun 2015-2017. Data yang digunakan dalam penelitian ini menggunakan data sekunder yang berasal dari data publikasi Badan Pusat Statistik (BPS). Variabel yang digunakan dalam penelitian ini adalah Indeks Pembangunan Teknologi Informasi dan Komunikasi (IP TIK) sebagai variabel dependen dan Indeks Pembangunan Manusia (IPM) sebagai variabel independen.

Metode analisis yang digunakan dalam penelitian ini adalah analisis deskriptif dan analisis inferensia. Analisis dekriptif digunakan untuk melihat gambaran umum pembangunan manusia di KTI, dan mengetahui hubungan antara pembangunan TIK dan pembangunan manusia di kawasan timur Indonesia. Analisis inferensia yang digunakan dalam penelitian ini adalah analisis regresi data panel. Analisis regresi data panel digunakan untuk mengetahui pengaruh IP-TIK terhadap IPM. 
Analisis regresi data panel adalah analisis yang menggabungkan antara data antar individu (cross-section) dan data runtun waktu (time series) (Gujarati, 2014). Model yang digunakan dalam analisis data panel yakni:

$$
\begin{aligned}
& \mathrm{Y}_{\text {it }}=\beta_{0}+\beta_{1} \mathrm{X}_{1 \mathrm{it}}+\beta_{2} \mathrm{X}_{2 \mathrm{it}}+\cdots+\beta_{k} \mathrm{X}_{\mathrm{kit}}++\varepsilon_{\mathrm{it}} \\
& \varepsilon_{\mathrm{it}}=\mu_{\mathrm{i}}+\mathrm{v}_{\mathrm{it}} \\
& \text { dengan, } \\
& \mathrm{i} \quad: \text { urut individu, } \\
& \mathrm{t} \quad: \text { urut waktu, } \\
& \beta_{0} \quad: \text { koefisien intersep, } \\
& \beta_{1,2, \ldots, k}: \text { koefisien slope, } \\
& \mathrm{Y}_{\mathrm{it}} \quad: \text { variabel dependen individu ke-i pada waktu ke-t, } \\
& \mathrm{X}_{\mathrm{it}} \quad: \text { variable independen individu ke-I pada waktu ke-t, } \\
& \varepsilon_{\text {it }} \quad: \text { komponen interferensi, } \\
& \mu_{\mathrm{i}} \quad: \text { efek individu, } \\
& \mathrm{v}_{\mathrm{it}} \quad: \text { variable acak. }
\end{aligned}
$$

Dengan demikian, dalam penelitian ini model yang akan diestimasi dalam penelitian ini adalah sebagai berikut,

$\mathrm{IPM}_{\mathrm{it}}=\beta_{0}+\beta_{1} \mathrm{IP}_{-} \mathrm{TIK}_{\mathrm{it}}+\varepsilon_{\mathrm{it}}$

dengan,

IPM $_{\mathrm{it}} \quad$ : Indeks Pembangunan Manusia provinsi i, pada tahun $\mathrm{t}$,

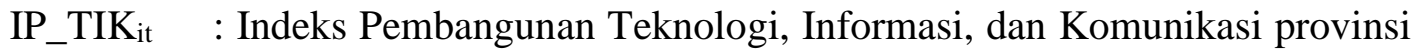
i, pada tahun $\mathrm{t}$,

Terdapat tiga model dalam proses estimasi parameter pada analisis regresi data panel (Baltagi, 2015), yakni:

\section{Common Effect Model (CEM)}

Model ini dikenal juga sebagai Pooled Regression Model (Gujarati, 2014). Model CEM mengasumsikan bahwa intersep masing-masing variabel adalah sama, begitu juga dengan slope koefisien untuk semua unit individu dan deret waktu (Melliana, 2013). Dengan kata lain, model ini mengabaikan variasi yang muncul dari individu dan waktu. Persamaan dari model ini dapat diformulasikan sebagai berikut:

$$
\mathrm{Y}_{\mathrm{it}}=\beta_{0}+\beta_{1} \mathrm{X}_{1 \mathrm{it}}+\beta_{2} \mathrm{X}_{2 \mathrm{it}}+\cdots+\beta_{k} \mathrm{X}_{\mathrm{kit}}+\mathrm{v}_{\mathrm{it}}
$$

2. Fixed Effect Model (FEM) 
Berbeda dengan CEM, FEM mengakomodasi adanya perbedaan efek yang diberikan antar individu. Dengan berbedanya efek yang diberikan antar individu makan intersep yang dihasilkan untuk tiap individu akan berbeda. Persamaan FEM dapat diformulasikan sebagai berikut:

$$
\mathrm{Y}_{\mathrm{it}}=\alpha_{i}+\beta_{1} \mathrm{X}_{1 \mathrm{it}}+\beta_{2} \mathrm{X}_{2 \mathrm{it}}+\cdots+\beta_{k} \mathrm{X}_{\mathrm{kit}}+\varepsilon_{\mathrm{it}}
$$

Indeks $i$ pada intersep $\left(\alpha_{\mathrm{i}}\right)$ digunakan untuk menyatakan bahwa intersep dari masing-masing individu berbeda.

\section{Random Effect Model (REM)}

Model REM memperkirakan variable error dapat saling berhubungan antara waktu dan antar individu. Perbedaan tersebut diakomodir melalui error. Persamaan REM dapat diformulasikan sebagai berikut:

$$
\begin{aligned}
& Y_{\text {it }}=\beta_{0}+\beta_{1} X_{1 i t}+\beta_{2} X_{2 i t}+\cdots+\beta_{k} X_{\text {kit }}+\varepsilon_{i t} \\
& \text { dengan, } \\
& \varepsilon_{\text {it }}=\mu_{\mathrm{i}}+v_{\text {it }}
\end{aligned}
$$

Selanjutnya, dari ketiga model tersebut dilakukan pemilihan model terbaik dan paling sesuai. Uji yang dilakukan untuk menentukan model terbaik dari 3 model tersebut yaitu:

\section{Uji Chow}

Uji ini digunakan untuk mengetahui apakah regresi data panel fixed effect model (FEM) lebih baik daripada common effect model (CEM). Hipotesis uji chow adalah sebagai berikut:

$\mathrm{H}_{0}: \mu_{1}=\mu_{2}=\cdots=\mu_{\mathrm{n}}=0(\mathrm{CEM})$

$\mathrm{H}_{1}$ : Paling tidak ada satu $\mu_{\mathrm{i}} \neq 0$ untuk $\mathrm{i}=1,2, \ldots, \mathrm{n}(\mathrm{FEM})$

Nilai dari uji chow akan dibandingkan dengan distribusi F, jika nilai F-statistik lebih besar dari F-tabel atau nilai peluang lebih kecil dari tingkat signifikansi $(\alpha=0.05)$ maka FEM lebih baik dibandingkan dengan CEM.

\section{Uji Hausman}

Uji ini digunakan untuk mengetahui mana yang lebih baik antara fixed effect model (FEM) dan random effect model (REM). Dengan hipotesis sebagai berikut:

$$
\begin{aligned}
& \mathrm{H}_{0}: \operatorname{cov}\left(\varepsilon_{\mathrm{it}}, \mathrm{X}_{\mathrm{it}}\right)=0(\mathrm{REM}) \\
& \mathrm{H}_{1}: \operatorname{cov}\left(\varepsilon_{\mathrm{it}}, \mathrm{X}_{\mathrm{it}}\right) \neq 0(\text { FEM })
\end{aligned}
$$


Nilai dari uji hausman akan dibandingkan dengan distribusi chi-squere, jika nilai $\chi^{2}$ statistik lebih besar dari $\chi^{2}$-tabel atau nilai peluang lebih kecil dari tingkat signifikansi $(\alpha=0.05)$ maka FEM lebih baik dibandingkan dengan REM.

3. Uji Breush-Pagan Lagrange Multiplier (LM)

Uji ini digunakan untuk mengetahui apakah random effect model (REM) lebih baik daripada common effect model (CEM). Hipotesis uji Breush-Pagan Lagrange Multiplier (LM) adalah sebagai berikut:

$$
\begin{aligned}
& \mathrm{H}_{0}: \sigma_{\mu}=0 \text { (CEM) } \\
& \mathrm{H}_{1}: \sigma_{\mu} \neq 0 \text { (REM) }
\end{aligned}
$$

Nilai dari uji Breush-Pagan Lagrange Multiplier (LM) akan dibandingkan dengan distribusi chi-squere, jika nilai $\chi^{2}$-statistik lebih besar dari $\chi^{2}$-tabel atau nilai peluang lebih kecil dari tingkat signifikansi ( $\alpha=0.05$ ) maka REM lebih baik dibandingkan dengan CEM.

Setelah didapat model terbaik, dilakukan uji asumsi klasik seperti uji normalitas, homoskedastisitas, non-autokorelasi, dan non multikolinieritas. Setelah memenuhi semua ui asumsi klasik dilakukan uji kesesuaian model dengan melihat nilai $\mathrm{R}^{2}$, adjusted $\mathrm{R}^{2}$, uji $\mathrm{F}$ dan uji t.

\section{HASIL DAN PEMBAHASAN}

Secara umum, Indeks Pembangunan Teknologi, Informasi, dan Komunikasi (IP TIK) provinsi di Kawasan Timur Indonesia (KTI) mengalami kenaikkan, tetapi relatif lambat. Sebagian besar provinsi di Kawasan Timur Indonesia memiliki angka IP-TIK dibawah angka nasional. Hal ini menunjukkan masih timpangnya pembangunan TIK di antara Kawasan Barat Indonesia dan Kawasan Timur Indonesia. 
IP TIK Provinsi di Kawasan Timur Indonesia 2015-2017

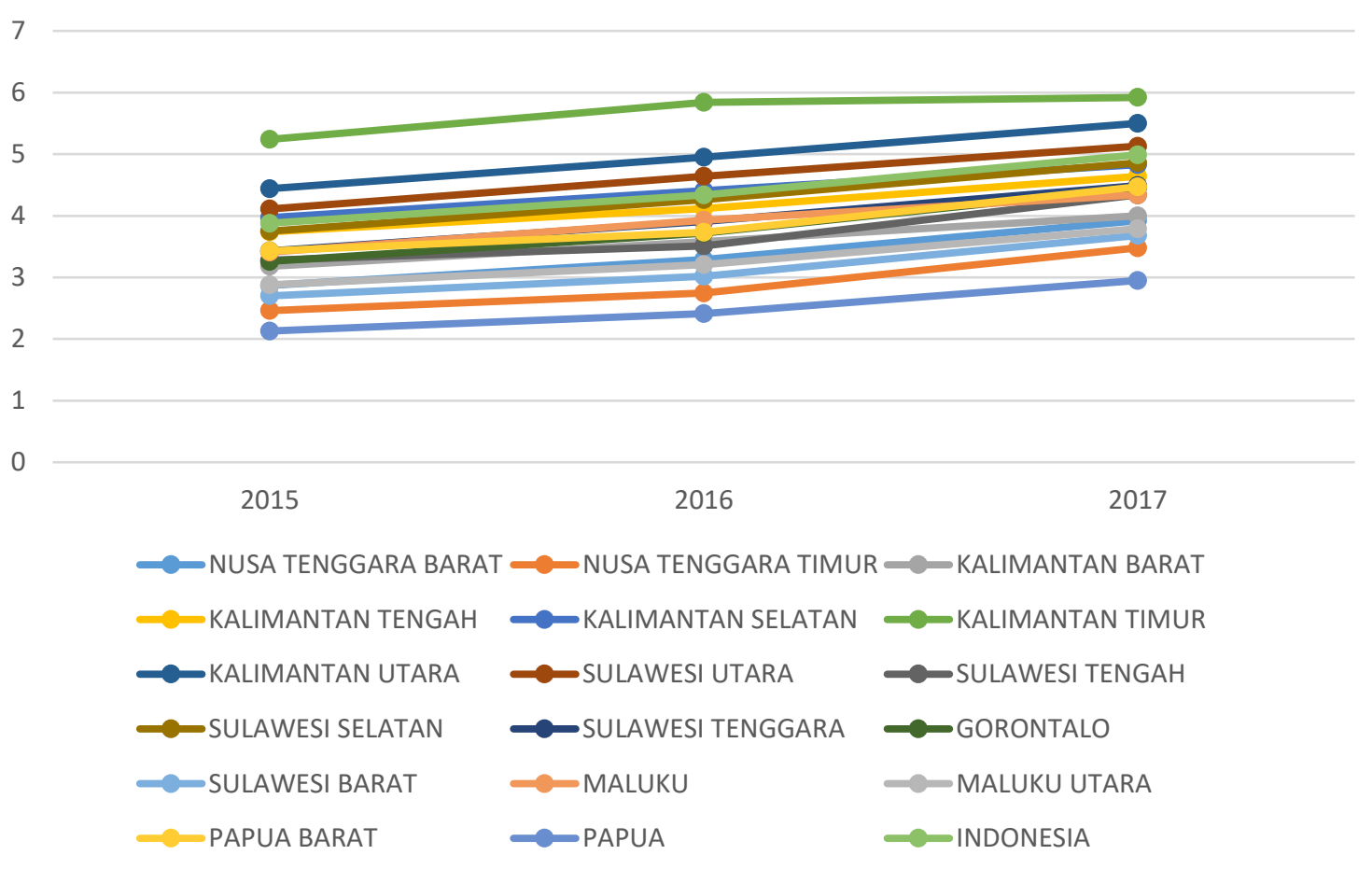

Gambar 2. IP TIK Provinsi di Kawasan Timur Indonesia 2015-2017

Dari gambar 2, dapat dilihat hanya ada 3 provinsi yang konsisten berada diatas angka nasional (hijau tua) yakni Provinsi Kalimantan Timur (hijau muda), Provinsi Kalimantan Utara (biru tua), dan Provinsi Sulawesi Utara (merah tua). Dari gambar tersebut juga dapat dilihat bahwa Provinsi di bagian paling timur Indonesia seperti Papua (biru) dan NTT (jingga) selalu berada di peringkat terbawah, dengan nilai indeks tidak sampai 3,5. Hal ini menunjukkan masih rendahnya pembangunan TIK di berbagai provinsi di Kawasan Timur Indonesia. 


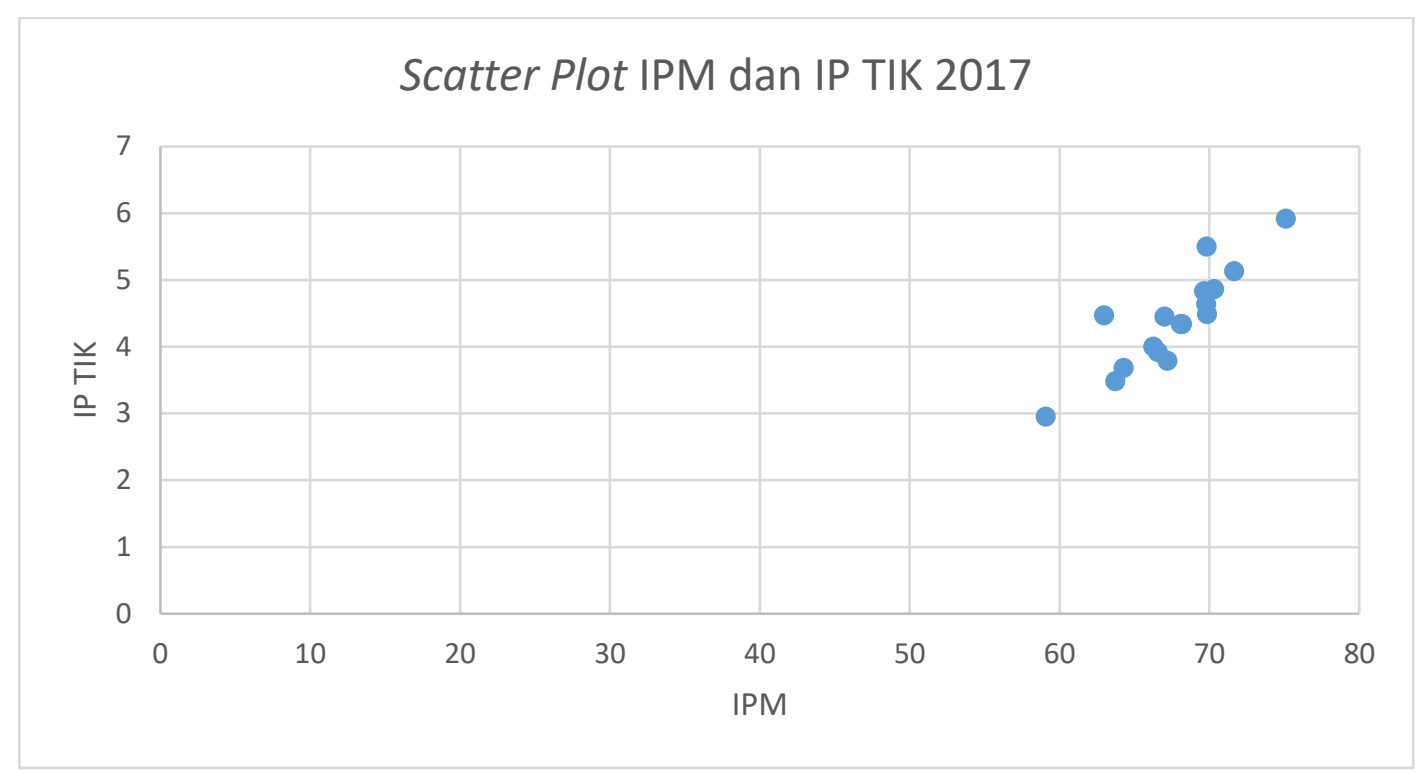

Gambar 3. Scatter Plot IPM dan IP TIK 2017

Dari Gambar 3, diindikasikan adanya hubungan antara pembangunan TIK dan pembangunan manusia di provinsi kawasan timur Indonesia. Diindikasikan semakin tinggi nilai IP TIK suatu provinsi maka semakin tinggi pula nilai IPM di provinsi tersebut. Dari perhitungan angka korelasi pearson, menunjukkan bahwa korelasi kedua indeks ini sebesar 0,87. Dengan demikian, disimpulkan bahwa kedua indeks ini memiliki hubungan yang kuat.

Selanjutnya dilakukan uji-uji untuk menentukan model yang terbaik antara CEM, FEM, dan REM. Uji Chow digunakan untuk mengetahui model mana yang lebih baik digunakan anatra CEM dan FEM. Hasil dari perhitungan uji chow menunjukkan tolak $\mathrm{H}_{0}$ yang berarti FEM lebih baik dari CEM.

Tabel 1. Hasil Uji Chow

\begin{tabular}{|l|c|c|c|}
\hline Uji & Statistik & d.f. & Peluang \\
\hline \multicolumn{1}{|c|}{$(1)$} & $(2)$ & $(3)$ & $(4)$ \\
\hline Cross-section F & 487,19 & $(16,33)$ & $<0.01$ \\
\hline Cross-section Chi-square & 278,92 & 16 & $<0.01$ \\
\hline
\end{tabular}

Sumber: Hasil pengolahan data menggunakan EViews 10

Setelah dilakukan uji chow, dilanjutkan dengan uji hausman. Uji ini digunakan untuk menenetukan model mana yang lebih baik antara FEM dan REM. Hasil dari uji hausman menunjukkan $\mathrm{H}_{0}$ ditolak, yang berarti FEM lebih baik dibandingkan dengan REM.

Tabel 2. Hasil Uji Hausman

\begin{tabular}{|c|c|c|c|}
\hline Uji & Chi-Sq. Statistik & Chi-Sq. d.f. & Peluang \\
\hline & $(2)$ & $(3)$ & $(4)$ \\
\hline
\end{tabular}




\section{\begin{tabular}{|l|r|r|r|} 
Cross-section random & 27.91 & 1 & $<0,01$ \\
\hline
\end{tabular}}

Sumber: Hasil pengolahan data menggunakan EViews 10

Dengan demikian model terbaik yang digunakan untuk mengetahui pengaruh pembangunan TIK terhadap pembangunan manusia di Kawasan Timur Indonesia adalah FEM. Kesimpulan ini senada dengan penelitian Agustina dan Pramana (2019) yang juga menyatakan FEM merupakan model terbaik. Hasil dari FEM menunjukkan adanya pengaruh positif dan signifikan IP TIK terhadap IPM. Hasil ini sesuai dengan yang dikatakan oleh Rosales, et al., (2019) dan Bankole, et al., (2011).

Tabel 3. Hasil Estimasi Parameter Menggunakan FEM

\begin{tabular}{|c|c|c|c|c|}
\hline Variabel & Koefisien & Std. Error & t-Stat & Peluang \\
\hline$(1)$ & $(2)$ & $(3)$ & $(4)$ & $(5)$ \\
\hline C & 62.34 & 0.22 & 277.87 & $<0,01$ \\
\hline IP_TIK & 1.20 & 0.06 & 20.94 & $<0,01$ \\
\hline \multicolumn{5}{|c|}{} \\
\hline R-squared & 0.999 & Adjusted R-squared & 0.998 \\
\hline
\end{tabular}

Sumber: Hasil pengolahan data menggunakan EViews 10

Angka adjusted $\mathrm{R}^{2}$ menunjukkan 99,8 persen berarti Angka IPM provinsi di Kawasan Timur Indonesia dapat dijelaskan oleh IP TIK sebesar 99,8 persen, sedangkan sisanya sebesar 0,2 persen dijelaskn faktor lain dliluar model. Dari hasil estimasi parameter menunjukkan bahwa setiap kenaikan 1 poin IP TIK akan meningkatkan 1,2 poin IPM provinsi di Kawasan Timur Indonesia, dengan asumsi vaiabel lain konstan.

Tabel 4. Efek Individu tiap Provinsi di Kawasan Timur Indonesia

\begin{tabular}{|c|l|r|}
\hline No & \multicolumn{1}{|c|}{ Provinsi } & \multicolumn{1}{c|}{ Efek } \\
\hline 1 & Kalimantan Timur & 5.47948 \\
\hline 2 & Sulawesi Utara & 3.135828 \\
\hline 3 & Sulawesi Selatan & 2.257039 \\
\hline 4 & Sulawesi Tenggara & 2.230265 \\
\hline 5 & Kalimantan Tengah & 1.805238 \\
\hline 6 & Kalimantan Selatan & 1.397522 \\
\hline 7 & Kalimantan Utara & 0.964617 \\
\hline 8 & Sulawesi Tengah & 0.650643 \\
\hline 9 & Maluku & 0.597013 \\
\hline 10 & Maluku Utara & 0.284649 \\
\hline
\end{tabular}




\begin{tabular}{|r|l|r|}
\hline 11 & Nusa Tenggara Barat & -0.51546 \\
\hline 12 & Gorontalo & -0.52952 \\
\hline 13 & Kalimantan Barat & -0.73783 \\
\hline 14 & Sulawesi Barat & -2.48309 \\
\hline 15 & Nusa Tenggara Timur & -2.64204 \\
\hline 16 & Papua Barat & -4.68629 \\
\hline 17 & Papua & -7.20806 \\
\hline
\end{tabular}

Sumber: Hasil pengolahan data menggunakan EViews 10

FEM mengasumsikan adanya perbedaan antar individu dapat diakomodasi dalam intersep. Provinsi Kalimantan Timur dan Sulawesi Utara memiliki nilai intersep yang lebih besar dibandingkan Provinsi lain di Kawasan Timur Indonesia. Sedangkan Provinsi Sulawesi Barat, NTT, Papua Barat, dan Papua memerlukan perhatian lebih untuk memajukan pembangunan manusia di daerah tersebut. Keempat provinsi tersebut memiliki nilai intersep paling rendah, yang berarti masih jauh tertinggal dalam pembangunan manusia dibandingkan provinsi lain di Kawasan Timur Indonesia.

\section{KESIMPULAN DAN SARAN}

Indeks Pembangunan Teknologi, Informasi, dan Komunikasi (IP TIK) provinsi di Kawasan Timur Indonesia (KTI) mengalami kenaikkan, tetapi relatif lambat. Beberapa provinsi seperti NTT dan Papua bahkan memiliki angka IP TIK yang relatif rendah.

Lebih lanjut, temuan penting dalam penelitian ini adalah IP TIK memiliki pengaruh positif dan signifikan terhadap IPM. Dari hasil estimasi parameter menunjukkan bahwa setiap kenaikan 1 poin IP TIK akan meningkatkan 1,2 poin IPM provinsi di Kawasan Timur Indonesia, dengan asumsi vaiabel lain konstan. Provinsi Sulawesi Barat, NTT, Papua Barat, dan Papua merupakan provinsi yang paling terbelakang dalam pembangunan manusia. Keempat provinsi tersebut memiliki nilai intersep individu paling rendah dibandingkan provinsi lain di Kawasan Timur Indonesia. Hal tersebut berarti keempat provinsi tersebut memerlukan perhatian lebih untuk memajukan pembangunan manusia di daerah tersebut.

Saran dari penelitian ini dalah perlunya usaha ekstra dalam meningkatkan pembangunan TIK di Indonesia khususnya wilayah timur. Dengan meningkatkan pembangunan TIK di Kawasan Timur Indonesia diharapkan dapat mengurangi ketimpangan pembangunan di Indonesia. Untuk penelitian selanjutnya diharapkan melakukan penelitian terkait dengan 
faktor-faktor yang memengaruhi pembangunan teknologi di provinsi yang berada dalam Kawasan Timur Indonesia.

\section{DAFTAR PUSTAKA}

Baltagi, B.H., 2005. Econometric Analysis of Panel Data 3rd Edition England JW \&Sons.

Bankole, F.O. ${ }^{A}$, Shirazi, F. and Brown, I., 2011. Investigating the impact of ICT investments on human development. The Electronic Journal of Information Systems in Developing Countries, 48(1), hlm.1-19.

Bankole, F.O., Brown, I. and Osei-Bryson, K.M., 2011, May. The impact of ICT infrastructure on human development: an analysis of ICT-Use in SADC countries. In Proceedings of the 11th International Conference on Social Implications of Computers in Developing Countries, Kathmandu, Nepal.

Bongo, P., 2005. The impact of ICT on economic growth (No. 0501008). University Library of Munich, Germany.

BPS Statistics Indonesia. 2016. Telecommunication Statistics Indonesia 2015.

BPS Statistics Indonesia., 2016. Official Statistics News (BRS). https://bps.go.id/website/brs-ind-2016121531927.pdf. Diakses tanggal 2 November 2019.

BPS Statistics Indonesia., 2017. Official Statistics News (BRS). https://bps.go.id/website/brs-ind-20171215094618.pdf. Diakses tanggal 2 November 2019.

BPS Statistics Indonesia., 2018. Official Statistics News (BRS). https://bps.go.id/website/brs-ind-20181217115247.pdf. Diakses tanggal 2 November 2019.

BPS Statistics Indonesia., 2014. Indeks pembangunan manusia. Tersedia pada http://www. bps. go. id/menutab. php.

Firdaus, M., 2013. Ketimpangan Pembangunan Antar Wilayah di Indonesia: Fakta dan Strategi Inisiatif. Institut Pertanian Bogor, Bogor.

Gujarati, D.N., 2009. Basic econometrics. Tata McGraw-Hill Education.

Maryati, S., 2015. Dinamika pengangguran terdidik: tantangan menuju bonus demografi di Indonesia. Economica: Jurnal Program Studi Pendidikan Ekonomi STKIP PGRI Sumatera Barat, 3(2), hlm.124-136.

Melliana, A. and Zain, I., 2013. Analisis Statistika Faktor yang Mempengaruhi Indeks Pembangunan Manusia di Kabupaten/Kota Provinsi Jawa Timur dengan Menggunakan Regresi Panel. Jurnal Sains dan Seni ITS, 2(2), hlm.D237-D242.

Minah, T., 2014. Politik Industrialisasi Di Korea Selatan (Studi Atas Peran Negara Dalam Pengembangan Teknologi Dan Industri Periode 1990-2002) (Bachelor's thesis, Fisip UIN Jakarta).

Morawczynski, O. and Ngwenyama, O., 2007. Unraveling the impact of investments in ICT, education and health on development: an analysis of archival data of five West African countries using regression splines. The Electronic Journal of Information Systems in Developing Countries, 29(1), hlm.1-15. 
Niebel, T., 2018. ICT and economic growth-Comparing developing, emerging and developed countries. World Development, 104, hlm.197-211.

Palenewen, T.O., Walewangko, E.N. and Sumual, J.I., 2018. Pengaruh Pengeluaran Pemerintah Sektor Pendidikan dan Sektor Kesehatan Terhadap IPM dan Dampaknya terhadap Kemiskinan di Sulawesi Utara. Jurnal Berkala Ilmiah Efisiensi, 18(4).

Rosales, H., Camacho Ballesta, J.A., Tamayo Torres, I. and Buelvas Ferreira, K., 2019, September. Effects of Information and Communication Technology Usage by Individuals, Businesses, and Government on Human Development: An International Analysis. Institute of Electrical and Electronics Engineers.

Sabbagh, K., Friedrich, R., El-Darwiche, B., Singh, M., Ganediwalla, S.A.N.D.E.E.P. and Katz, R.A.U.L., 2012. Maximizing the impact of digitization. The global information technology report, hlm.121-133.

Septanto, H., 2016. Ekonomi Kreatif dan Inovatif Berbasis TIK ala Gojek dan Grabbike. Bina Insani ICT Journal (OLD), 3(1), hlm.213-219.

Wahyuningsih, S., 2013. Dampak Indeks Konektivitas Teknologi Informasi dan Komunikasi (TIK) terhadap Pertumbuhan Perekonomian. Buletin Pos dan Telekomunikasi, 11(4), hlm.335-344.

Zuhdi, U., Mori, S. and Kamegai, K., 2012. Analyzing the role of ICT sector to the national economic structural changes by decomposition analysis: The case of Indonesia and Japan. Procedia-Social and Behavioral Sciences, 65, hlm.749-754. 